Abstracta Iranica Abstracta Iranica

Revue bibliographique pour le domaine irano-aryen

Volume 23 | 2002

Comptes rendus des publications de $\mathbf{2 0 0 0}$

\title{
Persia and the West. An Archaeological Investigation of the Genesis of Achaemenid Art. London, 2000, 255 p., nomb. ill.
}

\section{Astrid Nunn}

\section{(2) OpenEdition \\ 1 Journals}

Édition électronique

URL : http://journals.openedition.org/abstractairanica/35246

DOI : 10.4000/abstractairanica.35246

ISSN : 1961-960X

Éditeur :

CNRS (UMR 7528 Mondes iraniens et indiens), Éditions de l'IFRI

\section{Édition imprimée}

Date de publication : 15 mai 2002

ISSN : 0240-8910

Référence électronique

Astrid Nunn, "Persia and the West. An Archaeological Investigation of the Genesis of Achaemenid Art. London, 2000, 255 p., nomb. ill. », Abstracta Iranica [En ligne], Volume 23 | 2002, document 60, mis en ligne le 08 février 2010, consulté le 25 septembre 2020. URL : http://journals.openedition.org/ abstractairanica/35246 ; DOI : https://doi.org/10.4000/abstractairanica.35246

Ce document a été généré automatiquement le 25 septembre 2020.

Tous droits réservés 


\title{
Persia and the West. An Archaeological Investigation of the Genesis of Achaemenid Art. London, 2000, 255 p., nomb. ill.
}

\author{
Astrid Nunn
}

L'auteur s'attache à un de ses thèmes préférés: les formes d'art non-perse qui ont contribué à la formation de l'art achéménide perse. Un chapitre traite des différentes formes architecturales dans les satrapies de l'ouest et analyse les influences grecque, égyptienne ou levantine dans l'architecture achéménide; un autre chapitre commente la statuaire. Il est encore difficile de démêler l'écheveau oriental et grec dans les productions orientales. Il me semble néanmoins que les terres cuites orientales représentant des femmes vêtues, non évoquées ici, ont colporté de l'Iran à la Grèce des styles et des modes qui se reflètent dans les statues grecques faites dans d'autres matériaux. Les satrapies ont beaucoup contribué à enrichir l'art achéménide, tout en étant elles-mêmes des foyers d'arts éclectiques et parfois de très haut niveau. L'art de l'Anatolie achéménide par exemple a ses racines dans l'art local préachéménide. Certains éléments achéménides s'y sont greffés, éléments qui eux-mêmes dépendaient souvent de modèles non-perses. Le problème-clef, celui de l'apport grec à l'art achéménide, est traité avec beaucoup de délicatesse. Sans hellénocentrisme J. Boardman continue à considérer Hérodote comme une source sérieuse. Ce livre très lisible et bien illustré ne propose pas de nouvelles approches. Ce n'était d'ailleurs pas le but de l'auteur qui modestement ne veut nous donner qu'un (excellent) résumé pour les étudiants et les non spécialistes (p. 8). 
INDEX

Thèmes : 3.2.2. Pré-Achéménides et Achéménides

\section{AUTEURS}

ASTRID NUNN

Université de Munich (Allemagne) 